Krystian Szopa*, Marek Iwaniec*, Andrzej Golaś*

\title{
LOW FREQUENCY IDENTIFICATION OF CRITICAL STATES OF TRANSMISSION TOWER STRUCTURES
}

\begin{abstract}
Transmission towers are vital parts of the overhead power line infrastructures. Any damage to these supporting structures may result in decreased load-bearing capacity and, in consequence, their collapse. Failures of transmission towers are much more severe than power failures, as they not only cause interruption to the energy supply but can also result in considerable costs of infrastructure repairs and damage. Therefore, supporting structures of overhead power lines should be subjected to structural health monitoring. This paper presents a comprehensive database containing natural frequencies and strain energies of all elements for various (simulated) damage states. On the basis of structure modal parameters, by finding the correlation between natural frequencies of damaged structure stored in the created database and natural frequencies of the structure of interest, state of the test structure can be identified. In order to verify this method, a numerical experiment was carried out. Observing the strain energy variation as compared to the undamaged state makes it possible to localize the damage and assess its importance for the further structure exploitation.
\end{abstract}

Keywords: space frames, natural frequency, database, numerical analysis, damage detection

\section{IDENTYFIKACJA STANÓW KRYTYCZNYCH KONSTRUKCJI WSPORCZYCH NAPOWIETRZNYCH LINII ENERGETYCZNYCH}

Konstrukcje wsporcze stanowia istotna część infrastruktury napowietrznych linii elektroenergetycznych. Uszkodzenie konstrukcji stupa elektroenergetycznego może prowadzić do zmniejszenia nośności takiego obiektu, a w rezultacie do utraty jego stateczności i zniszczenia. Awarie konstrukcji wsporczych napowietrznych linii elektroenergetycznych sa o wiele bardziej niebezpieczne niż awarie powstałe z przyczyn elektroenergetycznych (np. awaria zasilania), gdyż powodują nie tylko przerwę $w$ dostawie energii elektrycznej, ale również moga skutkować kosztami poniesionymi w związku z naprawami i wypłata odszkodowań. Dlatego też stan techniczny konstrukcji słupów elektroenergetycznych powinien być monitorowany. Artykut przedstawia bazę danych zawierajaca różne (symulowane) stany uszkodzeń, wraz z przypisanymi do nich informacjami na temat częstotliwości drgań własnych obiektu oraz energii sprężystej poszczególnych elementów. Na podstawie własności dynamicznych obiektu, poprzez znalezienie korelacji pomiędzy częstotliwościami drgań własnych symulowanych stanów uszkodzeń konstrukcji, zapisanymi w bazie danych, a częstotliwościami drgań własnych badanej konstrukcji, stan techniczny badanej konstrukcji może zostać zidentyfikowany. W celu weryfikacji metody, przeprowadzono eksperyment numeryczny. Obserwujac zmiane energii sprężystej konstrukcji badanego obiektu w porównaniu z energią konstrukcji nieuszkodzonej, możliwe jest dokonanie oceny stanu technicznego badanego obiektu i określenie wplywu uszkodzenia na przyszła prace konstrukcji.

Stowa kluczowe: ramy przestrzenne, częstotliwości drgań własnych, baza danych, analiza numeryczna, detekcja uszkodzeń

\section{INTRODUCTION}

Overhead power lines are a very important part of the infrastructure in every country. They allow for the distribution of electricity in vast areas, supplying individual consumers, the industry, transport and the public sector. A power outage caused by a failure not only results in financial losses, but also causes a drastic reduction in the comfort and safety for the inhabitants of the area. One reason for the interruption of the energy supply can be directly related to the problem with electricity, such as a power plant failure. Another reason can stem from a mechanical problem, i.e. the physical damage of certain elements of the overhead power lines. In the latter case, damage to the power lines' supporting structures is the most dangerous problem. Any damage to the transmission tower structure may result in the loss of stability and, consequently, its collapse. In many such cases, a collapsing tower pulls on the power lines, causing cascading destruction of other transmission towers (Albermani et al. 2009). Failures of this type (Rao et al. 2010) are much more severe than power failures, as they not only cause interruption of the energy supply, but can also result in considerable costs of infrastructure repairs and damages. There are different causes of such failures. It can be long-term damage causing deterioration of material properties of certain elements of the structure due to ageing and corrosion. On the other hand, the damage may be directly caused by theft or breakage of certain elements (Sanayei et al. 2006). Therefore, supporting

* AGH University of Science and Technology, Faculty of Mechanical Engineering and Robotics, Krakow, Poland, kszopa@agh.edu.pl, iwaniec@agh.edu.pl, ghgolas@cyf-kr.edu.pl 
structures of overhead power lines should be subject to monitoring, which would allow the identification of critical points in individual towers (Yin et al. 2009).

In practical use, especially with constant monitoring, any calculations relating to the identification of damage and critical states should be made as quickly as possible. The specificity of the power line means that it is built of a relatively low number of transmission tower types repeated many times along the observed line. Therefore, the best solution seems to be building a numerical model of the transmission tower and performing multiple simulations to determine the critical conditions for a given tower type. Despite time-consuming calculations performed at this stage, one has to remember that such a database of critical conditions is prepared only once for every tower type, while using such a solution considerably speeds up the identification of damage in later monitoring stage. It should be noted that the concept of the critical condition means a condition of the transmission tower after damage (or a combination of damages) threatening the stability of the structure occurred. This raises another question, namely: which condition should be treated as critical? In response, the relevant criterion that would allow for judging it should be chosen. This problem can be solved by using statistical analysis conducted on a finite element (FE) model, with variations in strain energy in individual elements as a criterion.

The process of monitoring consists of comparing the tower actual state with the critical conditions stored in the database. In order to do this, comparable parameters should be selected (Wu and Li 2006). Since the study involves transmission towers, determining the modal model of a structure using operational modal analysis is a good solution (Zimmerman et al. 2008). Of all the modal parameters, natural frequency is most easily determined. The advantage of the natural frequency is that it can be calculated using a relatively small number of sensors, which is particularly important, since the use of accelerometers for all degrees of freedom (DOFs) of a structure as complex as a transmission tower is practically impossible (Yin et al. 2009). In addition, the estimates of modal damping and normal mode shapes yield an error that is 20 times higher than the estimate of natural frequency (Messina et al. 1998). If the natural frequency of the test structure and the numerical model representing a specific critical state are close to each other, it means that the stability of this object is at risk. This allows for a more thorough study of the structure and to decide if a given support structure requires renovation.

The method described above, along with the programme, can be applied to different types of structures designed as beam structures. This paper focuses on transmission towers. The tower is a supporting structure for the line, embedded in the ground directly or using a foundation. They can be divided into the tangent and angle towers. Tangent towers are light-weight structures, whose main purpose is to support the conductors. Angle towers have to be additionally able to withstand the tension powers. Therefore, they employ guy suspension. Since up to $90 \%$ of all poles are tangent towers, $\mathrm{H}$ and $\mathrm{O} 24$ tangent towers were studied. This paper presents the results for the former.

\section{DAMAGE STATE DATABASE CREATION}

The study considers supporting structures for a high-voltage overhead power line. A transmission tower is treated as a spatial frame structure; hence the FE model consists of rigidly connected beam elements. As mentioned in the previous section, the concept of critical condition means structural damage that threatens to significantly decrease the structures load-bearing capacity. The first step towards building a database is to model consecutive damage states of individual structural elements and to store all of them in a database. Damage can be modelled using various methods, e.g. as a decrease in the cross-sectional area of an element, a decrease in Young's modulus or a variation in its moment of inertia (Nobahari and Seyedpoor 2011). A variation in these parameters changes the stiffness of the component and, consequently, the global stiffness matrix, which in turn changes the modal parameters of the test object.

Strain energy is a function of the deformation of the system but, after some transformations, it can be expressed by means of stress, material properties, nodal displacements in finite element method (FEM) or applied forces. That is why using it as a criterion in static analysis using FEM is a convenient solution. The amount of variation in elastic energy in individual elements of the structure after the damage occurred is a measure of the stress and strain that occurred in parts of the object. For linearly elastic materials, strain energy density stored in object is expressed as:

$$
U=(1 / 2) \int \sigma_{V} \sigma^{T} \varepsilon d V
$$

where $\sigma=\left[\sigma_{x x} \sigma_{y y} \sigma_{z z} \sigma_{x y} \sigma_{x z} \sigma_{y z}\right]^{T}$ and $\varepsilon=\left[\varepsilon_{x x} \varepsilon_{y y} \varepsilon_{z z} \gamma_{x y} \gamma_{x z} \gamma_{y z}\right]^{T}$ are stress and strain column vectors, respectively.

Since the equations are solved using FEM, the strain energy density stored in element has to be presented as a function of nodal displacements:

$$
U=(1 / 2) \int_{V}\left\{u_{i}\right\}^{T}[B]^{T}[D]^{T}[B]\left\{u_{i}\right\} d V
$$

where matrix $D$ connects vector of strain with stress vector, strain displacements matrix $B$ includes derivatives of the shape function, which define the relationship between the coordinates of the node positions and the displacements of nodes in the element. After calculating the element stiffness matrix $K$, the equation can be expressed as:

$$
U=(1 / 2)\left\{u_{i}\right\}^{T}[K]\left\{u_{i}\right\}
$$

Comparing the strain energy of structural elements in the damaged condition with the energy of these elements in a healthy structure, we focus on the biggest changes in energy that occurred as a result of the damage. Let $U^{h}=$ $\left\{U_{1}^{h}, \ldots, U_{k}^{h}, \ldots, U_{n}^{h}\right\}$ means the vector of strain energy stored in all $n$ elements of healthy construction, and $U\left(X^{p}\right)=\left\{U_{1}^{p}, \ldots, U_{k}^{p}, \ldots\right.$, $\left.U_{n}^{p}\right\}$ denotes the vector of strain energy stored in elements for the predicted $p^{\text {th }}$ state of damage. The change in strain energy vector for the $p^{\text {th }}$ state of damage can be expressed as: 


$$
\delta U\left(X^{p}\right)=U\left(X^{p}\right)-X^{h}
$$

Vector $X^{p}=\left\{x_{1}^{p}, \ldots, x_{k}^{p}, \ldots, x_{n}^{p}\right\}$ represents the vector of damage to state $p$, whose elements $\left\{x_{k}^{p}, k=1, \ldots, n\right\}$ are indicative of the damage of all $n$ elements of the numerical model. The next section describes this vector in detail. Since the significance of the individual elements of the supporting structure, such as a transmission tower varies, calculating the relative change of energy is inadvisable. For example, you may find that the strain energy in an element of a frame structure that carries a very little load under the influence of a given state of damage is increased several times. The amount of this energy is, however, still very small as compared to the strain energy in the elements that bear the main load. Large actual changes of strain energy in the elements are the basis for selection of critical states.

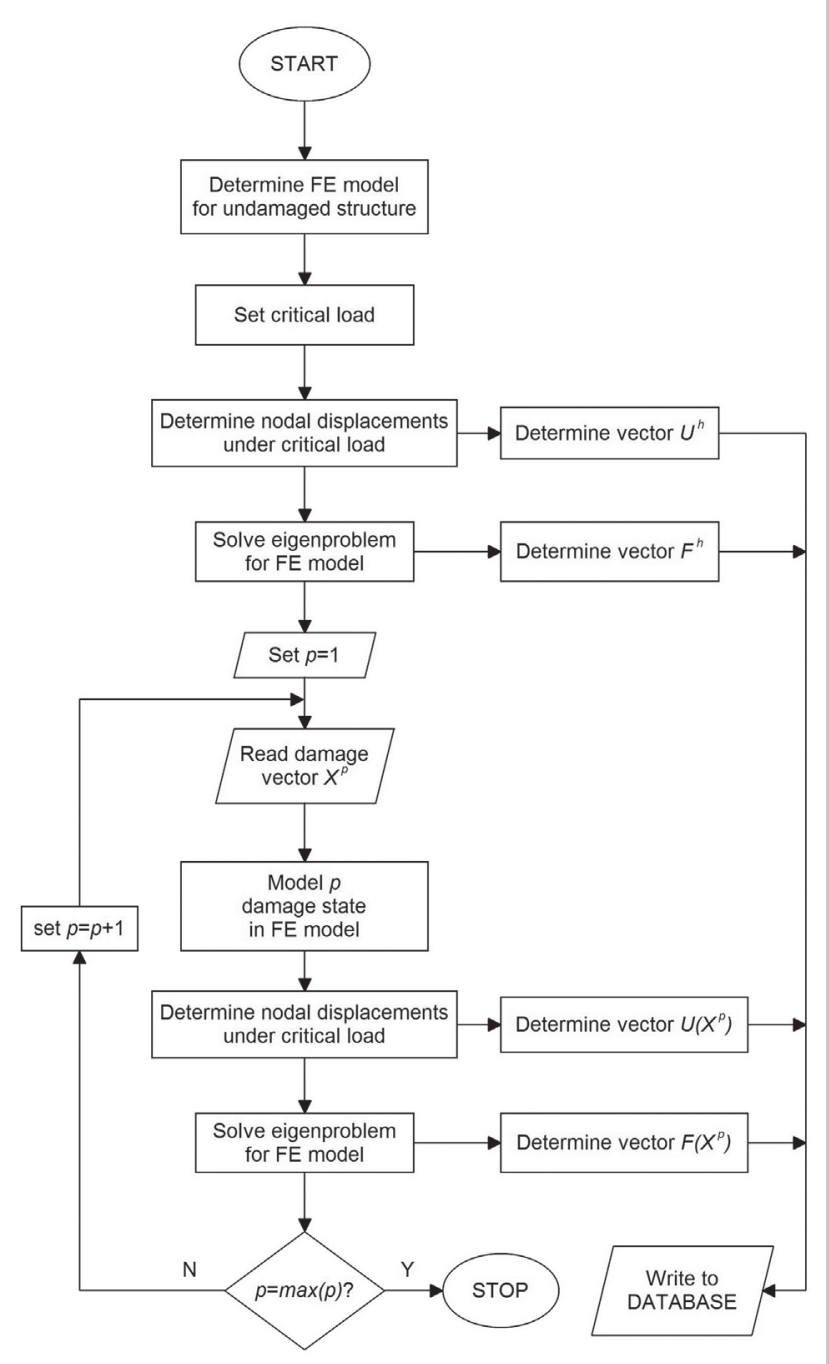

Fig. 1. The flowchart of a damage states database creation algorithm

In order to evaluate the technical condition of the tower, it is necessary to measure the parameters of the structure, which will serve as the basis for the identification of the structure's condition using the FE model. One of the methods used in the evaluation of the technical condition is an analysis of the dynamic properties of a structure. Unfortunately, when assessing the structure's conditions using commonly applied criteria such as MAC, COMAC (Allemang and Brown 1982, Allemang 2003), it is necessary to thoroughly learn the subsequent mode shapes, which involves the use of an increased number of vibration sensors for more complex structures and higher modes. If we consider the assessment of the technical condition of more objects of a similar type (e.g. transmission towers) and the relatively high cost of the sensors themselves, the aim is to minimize the number of sensors used in such a diagnostic system, particularly when the assessment of the technical condition of such a structure is not a one-off test but is subject to a long period of monitoring. Therefore, the desired solution in the evaluation of the technical condition of such structures would involve using just the amplitude-frequency characteristics of measured structure vibration, while its modes shapes would be used just for identification of appropriate modes and natural frequencies of the numeric model (Guo 2006).

Figure 1 presents an algorithm to create a database of structural damage states. The input consists of an FE model of the frame structure in question. Two analyses are performed: static and dynamic, which allows for determining the strain energy and natural frequency for a healthy state, with the data being stored in the database. Then, the damage for subsequent states $p$ of the test object is modelled. For each state, as in the case of a healthy structure, the strain energy and natural frequencies are calculated and stored in the database. The database thus includes information for each structural damage state, which consists of: type of damage, strain energy and natural frequency vector.

The database includes all simulated damage states, both the ones threatening the safety of a structure and those without considerable influence on it. Critical states can be selected at this stage by picking them from the database, though this paper uses all of the stored damage states to identify the condition of a transmission tower, and the assessment of criticality of a given state is performed at the very end.

\section{IDENTIFICATION OF THE TECHNICAL CONDITION OF A TRANSMISSION TOWER}

Among the dynamic values calculated as a result of a modal analysis, natural frequency vectors can provide important information in the process of assessing the technical condition of a given structure. By finding the level of correlation in natural frequency between the damage states stored in the database and the technical condition of a structure, we can assess their level of similarity. In (Messina et al.1996) was proposed the DLAC (Damage Location Assurance Criterion), whose concept is similar to the MAC. They later expanded this idea by ceating MDLAC (Multiple Damage Location Assurance Criterion) which, in contrast to DLAC, allowed for the detection of many faults in one structure. 
In (Koh and Dyke 2007, Nobahari and Seyedpoor 2011) authors expanded the application of these solutions in the assessment of the technical condition of a structure using genetic algorithms. Through the proper comparison of consecutive numerical models differing in damage indexes, we can choose a model which best reflects the actual structure, based on a comparison of natural and calculated frequencies. MDLAC serves as an assessment of such correlation (Messina et al. 1998).

In order to determine the parameters of a modal model without damping, the eigenproblem should be solved:

$$
K \phi_{i}-\Lambda_{i} M \phi_{i}=0
$$

where $M$ and $K$ denote mass and stiffness matrixes respectively, $\Lambda_{i}$ and $\phi$ are $i$-th eigenvalue and eigenvector. Equation (5) shows that mechanical parameters variation cause change in vibration characteristics of the system. Sensitivity theory allows to define the natural frequencies dependence of the change in mass and stiffness due to damage of the system:

$$
\frac{\partial f_{i}}{\partial x}=\frac{1}{8 \cdot \pi^{2} \cdot f_{i}} \cdot \phi_{i}^{T} \frac{\partial K}{\partial x} \phi_{i}-\frac{f_{i}}{2} \phi_{i}^{T} \frac{\partial M}{\partial x} \phi_{i}
$$

In (Messina et al. 1998) the authors proposed a model, that specifies the sensitivity of natural frequencies of all modes to element damage, defined as a homogeneous reduction of stiffness, with no change of mass:

$$
\frac{\partial f_{i}}{\partial x_{k}}=\frac{1}{8 \cdot \pi^{2} \cdot f_{i}^{h}} \cdot \frac{\phi_{i}^{h^{T}} \cdot K_{k}^{h} \cdot \phi_{i}^{h}}{\phi_{i}^{h^{T}} x_{k} \cdot M^{h} \cdot \phi_{i}^{h}}
$$

where $f_{i}^{h}$ and $\phi_{i}^{h}$ are $i^{\text {th }}$ natural frequency and mode shape vector, $K_{k}^{h}$ is the stiffness matrix of the $k^{\text {th }}$ element set in global matrix, $M^{h}$ is the global mass matrix, the superscript $h$ means the term applies to the undamaged structure. Factor $x_{k}$ denotes the damage state of the $k^{\text {th }}$ element, by stiffness reduction.

The model assumes that every natural frequency depends on a combination of damage size and location. Hence, frequency changes can be written as the sum of the products of sensitivities and damage states of all elements in the structure:

$$
S=\left[\begin{array}{ccc}
\frac{\partial f_{1}}{\partial x_{1}} & \cdots & \frac{\partial f_{1}}{\partial x_{n}} \\
\cdots & \cdots & \cdots \\
\frac{\partial f_{r}}{\partial x_{1}} & \cdots & \frac{\partial f_{r}}{\partial x_{n}}
\end{array}\right]
$$

$$
\delta F=S \cdot \delta X
$$

where $\delta F$ is the predicted vector of the natural frequency changes. The Size of this vector is $r$ and it is equal to the number of used modes. $\delta X$ is the damage vector and its length is equal to the number of all listed elements (Messina et al. 1998).

Nobahari and Seyedpoor described the predicted natural frequency change vector $\delta F$ in a slightly different form. The vector is dependent on the vector that consists of the damage extent of all elements. What is important, the damage extent takes discrete values. Vector $\delta F$ is expressed in the following form:

$$
\delta F\left(X^{p}\right)=\left(F^{h}-F\left(X^{p}\right)\right) / F^{h}
$$

where $F^{h}$ is the natural frequency vector of a healthy (undamaged) structure, $F\left(X^{p}\right)$ is a predicted vector of the natural frequency calculated from the numerical model. The length of both vectors is equal to the number of used mode shapes $r$. Vector $X^{p}=\left\{x_{1}^{p}, \ldots, x_{k}^{p}, \ldots, x_{n}^{p}\right\}$ represents the vector of the damage to state $p$. Damaging a given element of a structure usually involves a decrease in its stiffness. Changing parameters such as Young's modulus, geometric moment of inertia or cross-sectional area influences stiffness. That is why one of these parameters can be used to determine damage extent for individual elements. For example, if damage extent depends on the Young's modulus variation, the damage indicator of the $k^{\text {th }}$ element will be expressed as:

$$
x_{k}^{p}=\left(E_{k}^{h}-E_{k}^{p}\right) / E_{k}^{h}, \quad k=1, \ldots, n
$$

where $E_{k}^{h}$ means the tensile modulus of $k^{\text {th }}$ element in an intact structure, and $E_{k}^{p}$ denotes the tensile modulus of the $k^{\text {th }}$ element to state $p$, in which the damage occurred. It should be noted that the damage extent takes the value $x_{k}^{p}=0$ for the undamaged element and $x_{k}^{p}=1$ for $100 \%$ damage, opposite to the Messina method where $x_{k}=0$ is complete loss of the element. Of course every value from 0 to 1 , is proportional do the damage.

The second vector determining the change in the natural frequencies of the test structure as compared to a healthy structure is $\Delta F$ :

$$
\Delta F=\left(F^{h}-F^{d}\right) / F^{h}
$$

Given two vectors defining the variation of natural frequency, we can determine the MDLAC, that describes the degree of similarity between the test state of the structure and its models (Messina et al. 1998, Nobahari and Seyedpoor 2011).

$$
\operatorname{MDLAC}\left(X^{p}\right)=\frac{\left|\Delta F^{T} \cdot \delta F\left(X^{p}\right)\right|^{2}}{\left(\Delta F^{T} \cdot \Delta F\right) \cdot\left(\delta F^{T}\left(X^{p}\right) \cdot \delta F\left(X^{p}\right)\right)}
$$

It can easily be seen that MDLAC compares two vectors of frequency variation. One vector is derived from the result of studying the test structure, while the second one stems from numerical calculations. This criterion has a value between 0 and 1 , reaching a maximum when $\Delta F=\delta F\left(X^{p}\right)$.

Thus defined criterion of natural frequency correlation of the test structure and its model serve as the basis for the assessment of their similarity. Following the identification of the structure's state with one of the states stored in the database, we are left with the task of assessing if the technical condition should be classified as critical. In order to do this, a criterion based on absolute change in energy mentioned in chapter 2 was used. 


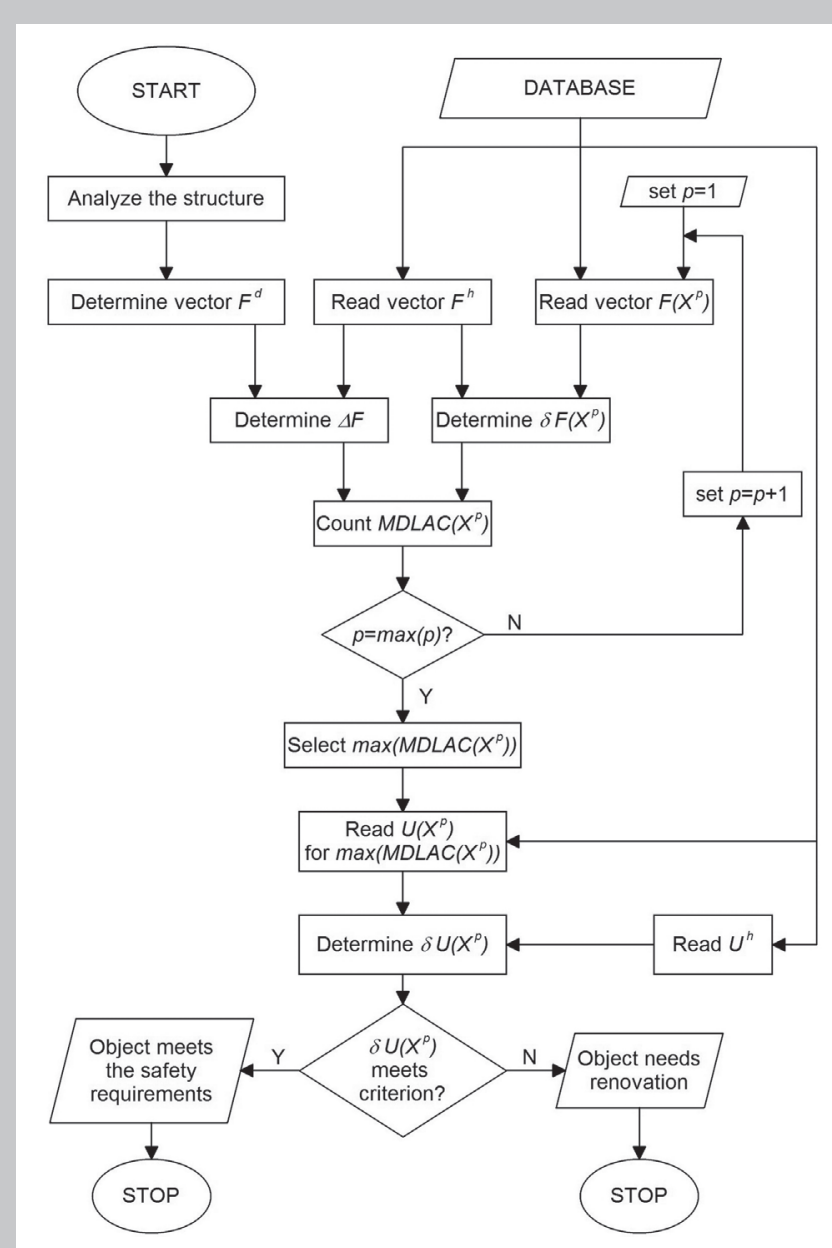

Fig. 2. The flowchart of a technical condition identification algorithm

Figure 2 shows the identification of the technical condition of a transmission tower algorithm. The test structure is compared, based on its natural frequency, to the models stored in the database. The energies of individual parts of the transmission tower for the numerical model most similar to the tested state are determined and then assessed. Depending on the assessment of the technical condition of the structure, it can be considered as safe or in danger. If it is found to be unsafe, it should be studied more thoroughly in order to make a decision concerning its renovation.

\section{NUMERICAL EXPERIMENT}

In order to verify this method, a numerical experiment was carried out. The study involved a high-voltage $110 \mathrm{kV}$, H-type transmission tower. The faced problem was solved with the use of the Strand7, software using the finite element method. The transmission tower was modelled as a spatial frame structure, so the FE model was constructed from 625 beam elements, rigidly connected in nodes (fig. 3). Because the influence of stiffness between the ground, foundations and steel part of the structure is omitted, the boundary conditions were assumed as rigid fastening structure to the ground. All degrees of freedom at the nodes lying at the base of the structure were fixed.

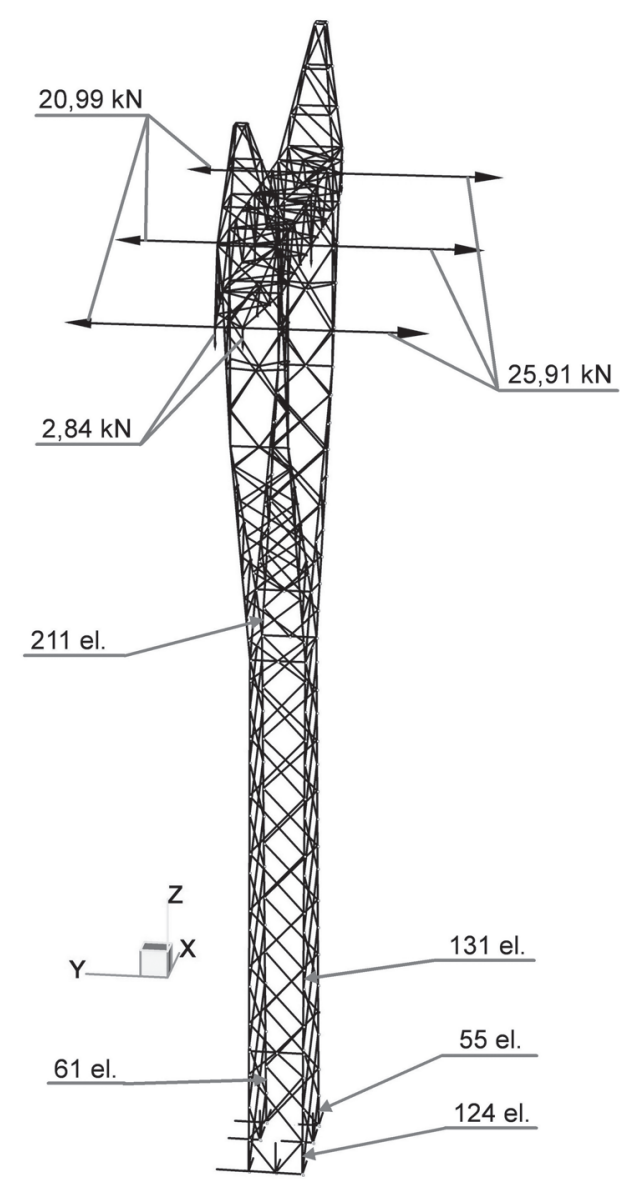

Fig. 3. Transmission tower geometric model

Loads were introduced as forces applied to the crown of the pole, coming from the guys and the weight of the conductors, as well as the gravitational acceleration allowing for taking the weight of the structure into consideration. A failure state was also introduced (Mendera et al. 2012), i.e. icing is distributed asymmetrically on the wires, leading to the asymmetric tower reaction.

\subsection{Database creating}

In order to create a database, structural damage was modelled as a decrease in Young's modulus of individual elements. At this stage, three discrete indicators of damage were adopted $x_{k}^{p}=0.3 ; 0.6 ; 1$. Values of 0.3 and 0.6 indicate a reduction of Young's modulus of the element 30 and $60 \%$, respectively, while the value of 1 means complete failure of the element. For each element damaged, a static and dynamic analysis was conducted, taking into consideration the three indicators of damage. The simulation yielded the strain energy of all elements, as well as the natural frequency vector for the test structure for each variant of damage and for a healthy structure. The calculations were stored in a database.

Due to the large number of beam elements of the test transmission tower, i.e. a large number of simulations, a programme had to be created that allowed for automating the calculations. Since the Strand7 environment was used for 
numerical calculations, an application which uses an API to connect to the CAE environment was developed in $\mathrm{C}++$. The program allows the user to choose whether to carry out simulations of a healthy structure, for a single damage or a combination of damages as well as how many first natural frequencies are to be calculated and saved. You can also select the option to create a completely new database or add new damage states to the already existing database. The creation of a database can be cancelled right away or after a certain cycle of calculations has been finished. The main window provides basic information about the tested structure, as well as the current simulations, which allows the user to track the creation of the database in real time. After the program is stopped, the right side shows a summary of the simulations, such as the elapsed time.

Since two analyses, static and dynamic, have to be conducted for each damage state, the time needed for an appropriate number of simulations is relatively long. The more complex the structure and the more elements it has, the longer the database creation time is. While creating a database for a single damage (after an appropriate number of damage indicators are chosen) is not much of a problem, creating a database for all possible combinations of damages in multiple elements is practically impossible. However, in the case of transmission towers, not all the elements are equally important for the stability of the structure. It should therefore be observed which elements bear the most loads and which elements are subject to the largest strain.

Simulation results show that the highest density of strain energy and stress for structure under modelled critical load conditions occurs in the legs and the outer edges of the tower just behind the arms fork. This allows for narrowing down the number of tested combinations of damage. The selected set of beams is input into an array, whose elements create various combinations of damage. A database was created for the example presented, consisting of 4500 damage states, which took less than 3 hours.

\subsection{Identification of the technical condition of a structure}

In order to verify the correctness of a given method, a numerical experiment should be conducted. For this purpose, some damage of the transmission tower structure will be modelled and a search will be performed on the database to find a state that corresponds to the damage state of the model. In order to study a single damage, one beam element 61 , located in one of the legs of the transmission tower, was selected (fig. 3).

The first damage case was modelled as a $45 \%$ reduction in Young's modulus of the selected item, while the second case reflected total damage. In both cases, vectors were created for natural frequencies for the first 15 modes and then compared to all vectors of natural frequencies stored in the database. In the first case, the maximum $\operatorname{MDLAC}\left(X^{62}\right)$ was 0.9989 for the frequency vector assigned to element 61 , for the damage indicator of $x=0.3$. The identification of damage is thus correct, as the indicator taken from the discrete values stored in the database is the closest value to the modelled indicator of 0.45 . This type of failure is stored in the database as 62. In the second case, the highest value $\operatorname{MDLAC}\left(X^{1312}\right)$ is equal to 0.9879 , which corresponds to the complete failure of element 61 stored as number $p=1312$. The MDLAC values for both cases are presented in figures $4 \mathrm{a}$ and $4 \mathrm{~b}$.

The third case was modelled as a complete breakdown of the two elements, 130 and 209 (fig. 3). Once the natural frequency vector for the test case was obtained, the highest value of $M D L A C\left(X^{2340}\right)$ of 0.9959 was obtained for the address 2340 (fig. 4c), corresponding to the complete failure of these very elements. The results of all three test cases are summarized in table 1 .

Table 1

MDLAC values for 3 damage cases

\begin{tabular}{|l|c|c|c|}
\hline \multicolumn{1}{|c|}{ Case } & 1 & 2 & 3 \\
\hline State $p$ & 62 & 1312 & 2340 \\
\hline Element 1 & 61 & 61 & 131 \\
\hline Element 2 & - & - & 211 \\
\hline Dmg [\%] & 45 & 100 & 100 \\
\hline MDLAC address & 62 & 1312 & 2340 \\
\hline MDLAC value & 0.9989 & 0.9879 & 0.9959 \\
\hline
\end{tabular}
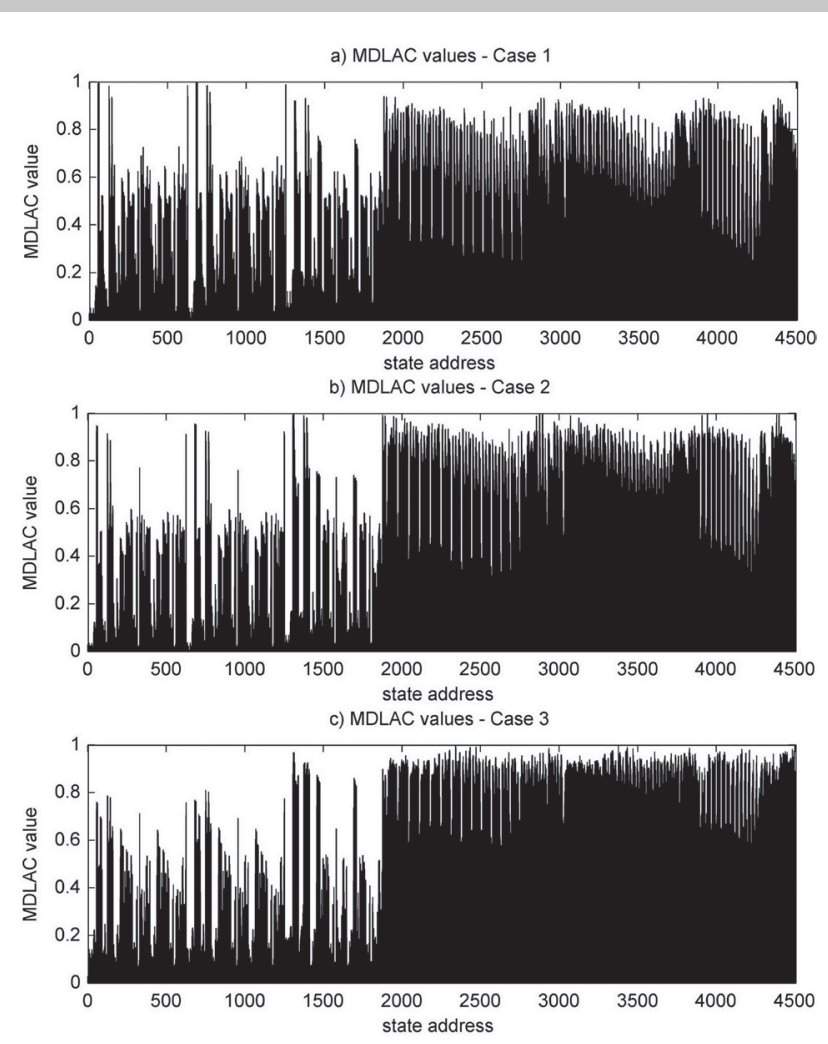

Fig. 4. Multiple damage location assurance criterion values for cases $1-3$

The numerical experiment shows that comparing natural frequency variation vectors allows for an effective comparison of the similarities between various states of the structure. It should also be noted (fig. 4), that the MDLAC variance for 
states from 2 to 1876 is much higher than for states from 1877 to 4504 . This is due to the fact that the first interval includes indicators for single damage, while the second interval relates to multiple damage.

\subsection{Critical states identification}

After the identification of damage, the technical condition of the transmission tower can be assessed. Observing the strain energy change as compared to the undamaged state allows for analysing the structure. Figure 5a shows the strain energy stored in the elements of an undamaged structure. All values are stored in the database, so at this stage it is not necessary to use the CAE software, which is not always available. Figure $5 \mathrm{~b}$ shows the difference, i.e. the change in strain energy for all elements between the identified damage state and the undamaged state $\delta U\left(X^{62}\right)=U^{62}-U^{h}, k=1,2, \ldots, 625$. It is worth noting that the difference is calculated as an absolute, rather than relative variation. This means that slightly loaded elements of an intact structure may increase their stored energy several times with a given damage state, even though these values are still small compared to the largest energy changes in the system. In the given case, the change in strain energy for each element is small and $\max \left(\delta U\left(X^{62}\right)\right)=0.70 \mathrm{~J}$ for element 124 . When analysing this case further, statistical analysis shows, that the maximum change in stress in this element is below $1.1 \%$, so this type of damage does not endanger the structure's stability.

Let us now consider the second case, where there was a complete breakdown of the element. It can be seen that the complete breakdown introduces considerable changes in strain energy of individual elements (fig. 5c), thus changing the distribution of stress throughout the transmission tower structure. Again, the greatest energy change occurs in element 124 , but the energy stored in the element is 2.74 times greater than in an undamaged structure. The stresses in the element are approximately 1.65 times higher than in an intact object. In both cases given above, the energy changes quadratically in relation to the variation in stress, which is caused by the fact that energy is a function of the square of the strain (for a FE model - the square of nodal displacements). Therefore, the energy method is more sensitive than basing the calculation on stresses alone.

Table 2

Maximum strain energy change in $k^{\text {th }}$ element for $p^{\text {th }}$ state

\begin{tabular}{|l|c|c|c|}
\hline \multicolumn{1}{|c|}{ Case } & 1 & 2 & 3 \\
\hline State $p$ & 62 & 1312 & 2340 \\
\hline Element $k$ & 124 & 124 & 55 \\
\hline$U^{h}$ for $k$ & 32.71 & 32.71 & 31.55 \\
\hline$U\left(X^{p}\right)$ for $k$ & 33.41 & 89.77 & 102.80 \\
\hline $\max \left(\delta U\left(X^{p}\right)\right)[\mathrm{J}]$ & 0.70 & 57.06 & 71.25 \\
\hline $\max \left(\delta U\left(X^{p}\right)\right)[\%]$ & 2.1 & 174.4 & 225.8 \\
\hline
\end{tabular}




\section{SUMMARY AND CONCLUSIONS}

This paper presents a method for identifying critical states in supporting structures of overhead power lines. The whole process can be divided into two stages. In the first stage, modal parameters are used to identify the condition of a transmission pole by determining the level of similarity to the damage states stored in the database. The second stage involves the assessment of this state based on the variation in elastic strain energy in individual elements of the structure under critical load conditions. Based on this assessment, a decision concerning the renovation of the test structure can be made.

The process of creating a database is an important part of the work. This paper presents the creation of a comprehensive database, with all simulated damage states, natural frequencies and energies of all elements. In order to reduce the time it takes to create this database, as well as its size, only an eigenproblem can be solved and only natural frequencies can be stored. The static analysis can be performed once a given state is identified. In this case, however, it is important that the person using the diagnostic system has constant access to the CAE software.

Additionally, the size of the database can be decreased by storing just the critical states, i.e. the states that warrant structure's renovation. Since conducting an analysis of all damage combinations is practically impossible, the simulated states have to be carefully chosen in order to shorten the time it takes to create the database as much as possible. Using genetic algorithms (Nobahari and Seyedpoor 2011) or artificial neural networks (Zhao et al. 1998) did may be a good solution to choose the best combinations. Certainly the database creation process itself may be improved, and the subsequent works should emphasize that.

The identification method itself is fairly effective. Using the natural frequencies, for which the estimation error is the lowest from among all modal parameters, we can determine the similarity level between the structure's state and the states stored in the database. If the MDLAC values for several states are similar, they should be considered and, in case of any doubt, a more thorough analysis should be conducted to assess the technical condition of the transmission pole. Since strain energy is the function of the square of strain (nodal displacements), calculating the elastic strain energy is a more sensitive method than the assessment of strain variations in elements.

The method is universal enough to work for virtually any beam construction and, with slight software modifications, can be adapted to other transmission towers structures, thus creating a diagnostic system for support structures in overhead power lines along their whole length.

\section{Acknowledgements}

The research was partially financed from the research project N R03 003410 "Diagnostic System for High Voltage Electric Transmission Lines" granted by The National Centre for Research and Development (NCBiR).

\section{References}

Albermani F., Kitipornchai S., Chan R.W.K. 2009, Failure analysis of transmission towers. Eng. Fail. Anal., vol. 16, pp. 1922-1928.

Allemang R.J., Brown D.L. 1982, A correlation coefficient for modal vector analysis. Proc. International Modal Analysis Conference, pp. 110-116.

Allemang R.J. 2003, The modal assurance criterion - twenty years of use and abuse. Sound and Vibration, August, pp. 14-21.

Battista R.C., Rodrigues R.S., Pfeil M.S. 2003, Dynamic behavior and stability of transmission line towers under wind forces. J. Wind. Eng. Ind. Aerod., vol. 91, pp. 1051-1067.

Guo H.Y. 2006, Structural damage detection using information fusion technique. Mech. Syst. Signal Pr., vol. 20, pp. 1173-1188.

Koh B.H., Dyke S.J. 2007, Structural health monitoring for flexible bridge structures using correlation and sensitivity of modal data. Comput. Struct., vol. 85, pp. 117-130.

Mendera Z., Szojda L., Wandzik G. 2012, Stalowe konstrukcje wsporcze napowietrznych linii elektroenergetycznych wysokiego napięcia. Wydawnictwo Naukowe PWN, Warszawa.

Messina A., Jones I.A., Williams E.J. 1996, Damage detection and localization using natural frequency changes, Proc., Conf., Identification In Engineering Systems, Swansea, UK, pp. 67-76.

Messina A., Williams E.J., Contursi J. 1998, Structural damage detection by a sensitivity and statistical-based method. J. Infrastruct. Syst., vol. 216 (5), pp. 791-808.

Nobahari M., Seyedpoor S.M. 2011, Structural damage detection using an efficient correlation-based index and a modified genetic algorithm, Math. Comput. Model., vol. 53, pp. 1798-1809.

Rao N.P., Knight G.M.S., Lakshmanan N., Iyer N.R. 2010, Investigation of transmission line tower failure. Eng. Fail. Anal., vol. 17, pp. $1127-$ 1141.

Sanayei M., Santini-Bell E., Javdekar C.N., Edelmann J.L., Slavsky E. 2006, Damage localization and finite-element model updating using multiresponse NDT Dat., J. Bridge Eng., vol. 11(6), pp. 688-698.

Wu J.R., Li Q.S. 2006, Structural parameter identification and damage detection for a steel structure using a two-stage finite element model updating method. J. Constr. Steel Res., vol. 62, pp. 231-239.

Yin T., Lam H.F., Chow H.M., Zhu H.P. 2009, Dynamic reduction-based structural damage detection of transmission tower utilizing ambient vibration data. Eng. Struct., vol. 31, pp. 2009-2019.

Zhao J., Ivan J.N., DeWolf J.T. 1998, Structural damage detection using artificial neural networks. J. Infrastruct. Syst., 4(3), pp. 93-101.

Zimmerman A.T., Shiraishi M., Swartz R.A., Lynch J.P. 2008, Automated modal parameter estimation by parallel processing within wireless monitoring systems. J. Infrastruct. Syst., 14, SPECIAL ISSUE: New Sensors, Instrumentation and Signal Interpolation, pp. 102-113. 